\title{
Reality Construction of Gamers in Online Media (Case Study : Kompas.Com)
}

\author{
Hafizh Faikar Ramadhan ${ }^{1}$, Euis Komalawati ${ }^{2}$ \\ $\left\{\right.$ insanetheory1212@gmail.com ${ }^{1}$ e_komalawati@yahoo.com $\left.{ }^{2}\right\}$
}

Universitas Indonesia, Indonesia $^{1}$, Institut Ilmu Sosial dan Manajemen Stiami, Indonesia ${ }^{2}$

\begin{abstract}
Gamers as a term for online game players initially had a negative stigma as a lazy and antisocial group. But along with the industrial revolution 4.0, many studies have shown changes in the stigma of gamers in the community. Changes in the pattern of thinking or the view of society towards gamers is not separated from social construction. Peter L. Berger and Thomas Luckmann view social reality as a dialectical process that passes externalization, objectivation and internalization. This research is to find out the reality construction of gamers in kompas.com online media. With the Pan \& Kosicki framing method, the analysis unit of this study is 5 article text gamers news on kompas.com. The results showed kompas.com frame the reality of gamers in a positive stigma in the discourse of promising professional opportunities, opportunities for e-sports athletes, and the phenomenon of the opening of current study programs in universities.
\end{abstract}

Keywords: Construction of Reality, Gamers, Framing.

\section{Introduction}

The term "game" was first introduced by Edward U. Condon in 1940. At that time game was created to prove that computer capabilities can exceed human capabilities. This first game was very simple, namely by competing with computers to take matchstick alternately with certain rules until the winner is the one who does not take the last matchstick. This first game was exhibited at the World's Fair at Westinghouse and the result was $90 \%$ of the games won by computers ${ }^{1}$.

Moving on from Edward's game which succeeded in attracting the enthusiasm of the participants at the prestigious exhibition, other games began to be developed, but due to inadequate technological limitations, the development of the game was still very limited..

A big jump in the game world occurred in 1964. A scientist named John Kemeny introduced the first Basic Programming Language. A language that facilitates communication between humans and machines. Simplification of binary is a word that is quite easy for ordinary people to understand. This is where countless new games are created and continue to grow along with the development of technology to date ${ }^{2}$.

The long journey of game development is certainly not possible if the game is not able to attract the interest of users and developers. According to Ernest Adam(2010), "A game is a

\footnotetext{
${ }^{1}$ https://theflame.unishanoi.org/lifestyle/2015/05/12/history-of-video-games/ , accessed on June 232019 at 19.30

${ }^{2}$ Durham and London,1992, Toward History of Game Theory, London, Duke University Press
} 
type of play activity, conducted in the context of apretended reality, in which the participant(s) try to achieve at least one arbitary, nontrivial goal by acting in accordance with rules". Based on that understanding, we can see that users / gamers from a game will be required to complete at least one challenge with certain rules. What makes the game unique and fun is that after one challenge is complete, the level of gamers will increase and presented with the next challenge that is more complicated. Unlike other media such as radio and television, in the game, gamers communicate directly with the "environment" deliberately created by game developers thus they drift away and feel themselves as if they were right there.

The nature of game like that raises the phenomenon of 'second self or second life', which means, the player has a personality or life both after his real life which is commonly called virtual life (Henry, Khamadi 2016). Furthermore, the game itself is able to present the simulation world (simulakra) for the players. In the world of simulation, there is no reference between signs and reality in the real world. Simulation is the second reality which refers to itself (simulacrum of simulacrum). Simulation does not have a direct relationship with the world of reality. Language and signs in simulation as if become the real reality, it is artificial reality. The reality of a simulation creation at a certain level will be seemingly (trusted) as well as real and even more real than the real reality. Simulation creates another reality beyond factual reality (hyperreality). In this sense, simulations create new realities or rather imaginary realities that are considered real ${ }^{3}$ (Bagong Suyanto, 2010).

Seeing the phenomenon above, it is not uncommon for gamers to become addicted. Kusumadewi (2009) mentioned the most common threat when a person is addicted is his inability to regulate emotions. Individuals often feel the feelings of sadness, loneliness, anger, shame, fear of going out, being in a situation of high family conflict, and having low selfesteem in their real life. This affects relationships with other people. Addicts also have difficulty distinguishing between games or fantasy and reality. Therefore, it is not surprising if the public gives a negative stigma towards gamers, whether it is said to be anti-social, lazy, and so on.

In the era of industrial revolution 4.0 today, the development of the game is increasingly stunning, both in terms of graphics and gameplay. The entry of games in the online world has led to possible unlimited interactions between gamers around the world, coupled with the development of games on smartphone media, making it possible to play anytime and anywhere. These things certainly increase the risk of more severe addiction to gamers. Strangely, the negative stigma that emerged in the community towards these gamers actually declined, even tending to give a positive stigma.

The positive stigma can be seen from the results of surveys in 11 countries carried out by the official AliWere YouTube account which is displayed through infographics ${ }^{4}$. The results show that today terms like nerd or geek that represent gamers, fans of comics and films are now also seen as positive nicknames. Gaming activities are also now considered as something cool and fun, which simultaneously increases the ability to lead, the ability to think critically, to motor skills such as spatial attention and hand-eye coordination.

Contrary to gamers who are often described as lazy and obese, the study found that at least $40 \%$ of gamers like to do sports activities. Then gamers who are screened as loner and rarely socialize, the results of these studies actually show the opposite, even willing to

\footnotetext{
${ }^{3}$ The theory of Simulacra is also in line with Jean Baudrillard's book, Simulacra and Simulation, terj. ShailaFaria Glaser (Michigan)

${ }^{4}$ https://www.youtube.com/watch?v=Op8EIkYJPlg accessed on June 232019 at $19.40 \mathrm{WIB}$
} 
sacrifice playing time for social activities such as hanging out and birthday events for example.

Changes in the pattern of thinking or the view of society towards gamers is not separated from social construction. The term social construction or reality became famous since first introduced by Peter L. Berger and Thomas Luckmann through their book entitled: The Social Construction of Reality, a Treatise inthe Sociological of Knowledge (1996). The two sociology scientists describe social processes through their actions and interactions, where individuals create continuously a reality that is owned and experienced together subjectively.

This social basis of theory and approach is the modern-transition society in America around the $1960 \mathrm{~s}$, where the mass media had not yet become an interesting phenomenon to talk about. Thus, the theory of social construction of the reality by Peter L. Berger and Thomas Luckman do not insert mass media as influential variables or phenomenain social construction of reality.

Along with the development of the times, in the book Construction of Mass Social Media (2015), the theory and social construction approach to reality by Peter L. Berger and Thomas Luckman have been revised by looking at variables or mass media phenomena to be substantial in the circulation of information quickly and widely thus social construction can take place very quickly with an even distribution.

As one of the most popular mass media in Indonesia; Kompas also took part in social reconstruction. Moreover, since 2008 Kompas has spread its wings on the online media scene with the name kompas.com thus the news or articles displayed are easier to consume. We can see this in the research of Slamet Dodi Kresno regarding corruption cases involving the Director of Police, Inspector General Djoko Susilo who allegedly received bribes of Rp.2 billion. The study was conducted by Robert N. Entman's framing or framing analysis method. Based on Robert Entman's framing analysis, the reality reconstruction process can be seen in two major dimensions, namely issue selection and emphasis or prominence of certain aspects of reality / issues. Based on the results of research conducted on Kompas.com news, two aspects were highlighted in the news, namely the issue of law enforcement and social politics.

Regarding the community's view of gamers, Kompas.com also contains articles related to this. If we enter the keyword "gamers" in the search column, you can find more than 68,500 results. Framing of these articles contributed greatly to the social construction that occurred in Indonesian society regarding their views on gamers.

Based on the explanation above, this study intends to find out how the reality construction of gamers in kompas.com online media through the framing approach.

\section{Theoretical Review}

The construction of reality gamers in online media uses the Reality Construction approach proposed by Berger and Luckmann. According to this theory social reality uses several concepts and terms (key words), namely externalization, objectivation, and internalization. Externalization is an attempt to pour out human beings into the world, both in mental and physical activities ${ }^{5}$.

Externalization is social interaction between humans and existing social structures. In externalizing each individual takes into account typifications. Typification is the basis of how

${ }^{5}$ Peter L. Berger, Thomas Luckmann (1967).The Social Construction of Reality, aTreatise in the Sociological of Knowledge.London : Penguin Books 
others are understood and treated in social interactions. Social change occurs when the externalization of individuals undermines the already established social order, replaced by a new order. Of all that, if we look for the basic assumption of externalization, people are formed because of humans ${ }^{6}$.

While objectivation is a process of self-manifestation (disclosure of subjective reality) into the forms of available activities that can be known by others as elements of the shared world. An example of an objective is, when someone is angry throws a gun. The act of removing weapons is interpreted by others as an objective reality that the person is angry. Being internalized is the understanding or direct interpretation of an objective event as a disclosure of meaning. Or understanding the subjective processes of others becomes meaningful to us.

This duality is used by Berger and Luckmann to build the basic premise of social construction theory over reality. The reality faced by humans can be returned to the dialectic between the animal side and its social side. First of all, it is certainly a factor of the human organism. The next question is how is social order enforced? Where is the origin of social order actually? In Bergerian's perspective, social order is a human product, or rather, an ongoing human production.

Social order is the result of externalization processes, not something that originates biologically, or derived from biological data in the embodiment of empiricism. Social order is not part of the "nature of things", nor is it derived from "natural laws". Social order exists only as a product of human activity. But social order is inseparable from biological factors, however, between them there is a dialectical process that never ends. In this way, Berger and Luckmann In order to understand further about the formation of social order, a theory of institutionalization is needed ${ }^{7}$.

\section{Research Methodology}

This study uses the constructivism paradigm which views the reality of social life as not a natural reality, but is formed from the results of construction. Therefore, the concentration of analysis in the constructionist paradigm was to find out how the event or reality is constructed, in what way the construction is formed. In the study of communication, this constructionist paradigm is often referred to as the production paradigm and the exchange of meaning. It is often opposed by the positivist paradigm or the transmission paradigm ${ }^{8}$.

Data collection method was descriptive qualitative method. According to Taylor \& Bogdan (1984), qualitative data is in the form of descriptive, which can be in the form of oral or written words about observed human behavior. In this study, the data used as a reference for research was written data or articles related to gamers on kompas.com

Furthermore, to analyze existing data, the researcher chose to use the Zhongdang Pan and Gerald M Kosicki framing analysis model that defines that framing is a process of making a message more prominent, placing more information than others thus the audience is more focused on the message, (Eriyanto , 2009). In addition, the researcher determined using the Zhongdang Pan and Gerald M Kosicki models because the four framing analysis device structures were syntax, script, thematic, and rhetorical to help a related theme in a news construction element.

${ }^{6}$ Ibid

${ }^{7}$ Ibid 


\section{Data Findings}

The following is a framing analysis of 5 articles about gamers posted on kompas.com.

Table 1. Analysis of Framing First Article

\begin{tabular}{|c|c|}
\hline Framing Device & Finding Result \\
\hline \multirow[t]{2}{*}{ Syntactic Structure } & $\begin{array}{l}\text { Title : For "Gamers", Take a Look at the Current } \\
\text { Study Programs at Several Indonesian } \\
\text { Campuses }\end{array}$ \\
\hline & $\begin{array}{l}\text { Lead : Study programs related to "Game" is } \\
\text { current study programs }\end{array}$ \\
\hline Script Structure & $\begin{array}{l}\text { The entire news content is almost complete, in } \\
\text { this article it is explained why the Game } \\
\text { Development Department is important, in which } \\
\text { Campus Game Developer study program is } \\
\text { opened, what is learned and what are the } \\
\text { advantages and specialties of each campus }\end{array}$ \\
\hline Thematic Structure & $\begin{array}{l}\text { 1. Industrial Revolution } 4.0 \\
\text { 2. Fields with rapid development in the } \\
\text { Industrial Revolution } 4.0 \text { is Games } \\
\text { 3. The education industry provides study } \\
\text { programs related to Game production } \\
\text { 4. Whatever students get from the study } \\
\text { program and which campus provides the } \\
\text { study program }\end{array}$ \\
\hline Rhetorical Structure & Use of the phrase "Current Study Program" \\
\hline
\end{tabular}

Table 2. Analysis of Framing Second Article

Framing Device $\quad$ Finding Result

$\begin{array}{ll}\text { Syntactic Structure } & \begin{array}{r}\text { Title : The Five Largest Income Gamers in } \\ \text { Indonesia Lead : Playing games is no } \\ \text { longer just for fun but is able to } \\ \text { provide income }\end{array} \\ \begin{array}{l}\text { Script Structure } \\ \text { The entire contents of the article only explain } \\ \text { how much and what tournament is won by each } \\ \text { game player and how much money is earned } \\ \text { without explaining how and why they can win the } \\ \text { tournament }\end{array} \\ \begin{array}{l}\text { 1. Game players can now make fantastic } \\ \text { amounts of money }\end{array} \\ \begin{array}{l}\text { 2. Currently games is used as a sports branch } \\ \text { known as e-sport } \\ \text { The game players who managed to make a } \\ \text { lot of money and tournaments won }\end{array} \\ \text { Rhetorical Structure }\end{array}$

Source : the article was published on kompas.com on April 25, 2019 
Table 3. Analysis of Framing Third Article

Framing Device

Syntactic Structure

Script Structure

Thematic Structure

Rhetorical Structure

Source : the article was published on kompas.com on March 18, 2019

\section{Finding Result} DPR RI
Title : 200 Gamers Ikuti Ajang NXL Mobile Esports Cup 2019

200 Gamers Join the 2019 NXL Mobile Esports Cup

Lead : Winning e-sport $=$ make the country proud Opinion of Mr. Charles as Commission 1 of the

Almost the entire contents of the article cite the opinion of Mr. Charles about the involvement of Indonesian gamers in the 2019 NXL Mobile Esport Cup event and his hopes

Use of the phrase "Make the name of the country", and use the word "positive" repeatedly

Table 4. Analysis of Framing Fourth Article

\section{Finding Result}

Title :Jokowi is curious to Gamers of "Mobile Legends, Jess No Limit

Lead :Gain income by becoming a gemer is an opportunity in this era

Opinion of Jokowi

In the paragraph by paragraph the journalist narrates in detail about Jokowi's speech at the 2018 Young on Top National Conference at Balai Kartini followed by quoting Jokowi's statements which essentially assume that in this era young people must take advantage of opportunities, one of which is earning income as gamers

Rhetorical Structure

The repeated use of the word "opportunity" Jokowi's remarks: Just like me, at first I would nag when my children play games, I'd say, 'Hey, what are you playing all day?' But apparently playing Mobile Legends but can bring money. This is what is called opportunity 
Table 5. Analysis of Framing Fifth Article

\begin{tabular}{|c|c|}
\hline Framing Device & Finding Result \\
\hline \multirow[t]{2}{*}{ Syntactic Structure } & $\begin{array}{c}\text { Title : Efforts to popularize gamers as the } \\
\text { chosen profession in Indonesia }\end{array}$ \\
\hline & $\begin{array}{l}\text { Lead : How the government made parents } \\
\text { aware that this entertaining sport (e- } \\
\text { sport) can be used as a profession }\end{array}$ \\
\hline Script Structure & $\begin{array}{l}\text { Opinions from Representatives of Surakarta } \\
\text { Youth \& Sports Service and Government } \\
\text { (Jokowi) }\end{array}$ \\
\hline Thematic Structure & $\begin{array}{l}\text { 1. Playing games in the country is still } \\
\text { considered entertainment only and not } \\
\text { useful } \\
\text { 2. With the emergence of e-sports, games } \\
\text { can be used as a profession } \\
\text { 3. Excerpt from Suhanto's representative } \\
\text { about the program to introduce i-sport } \\
\text { with assistance from the government } \\
\text { 4. Support from the government and } \\
\text { institutes can make parents better } \\
\text { understand e-sport. }\end{array}$ \\
\hline Rhetorical Structure & $\begin{array}{l}\text { Repeatedly emphasized on "Guidance to Gamers" } \\
\text { and "Parental Awareness" }\end{array}$ \\
\hline
\end{tabular}

Source : the article was published on kompas.com on October 25, 2017

\section{Analysis And Interpretation}

In social life, humans interact with each other. Social interaction between online gamers applies to existing social structures. Social interaction in the structure of society is a form of externalization. In externalizing each individual takes into account typifying. Gamers in social interactions have typifications that are understood in society in various types. In the beginning, gamers were understood as a game to kill time and cause addiction to other deviant behaviors. This understanding results in the treatment of gamers with a negative stigma.

Along with the development of 4.0 technology, bursting in every line of life is no exception for gamers. The development of types of games and technology gave birth to different typifications for gamers as a new opportunity in an era of disruption that changed the old system in new ways. This change in typification gradually changes the social order and stigma about gamers, as a result of social change.

Objectivation of gamers is a process of self-manifestation (disclosure of subjective reality) into the forms of available activities that can be known by others as elements of the shared world. In framing by kompas.com, the manifestation of gamers' actions was appointed as a new opportunity in the era of 4.0 industrial revolution, gamers were manifested as promising e-sports athletes and new professions that challenged universities to open "current" study programs.".

The original gamers' meaning had a negative understanding and stigma at first, framed by kompas.com with things that were different from the initial stigma. The process of 
internalization, that is, the understanding or immediate interpretation of the concept of gamers in our society initially leads to the expression of groups that tend to be negative. But the subjectivism process that is computed in kompas.com about gamers shows the diversity of subjectivity, which in social interaction brings together two or more subjectivities. Internalization which is the earliest base in the understanding of the social reality of gamers that is composed by kompas.com as a "contemporary" thing and a promising new profession, peaking up to a certain degree of internalization supporting the process of socialization.

The social process of maintaining the reality of gamers is carried out, among others, by socializing identity. The identity of gamers formed through kompas.com online media was identified because there was a distinction between self and significant others. The function of the other, in addition to asserting identity, is also to reaffirm the reality that is maintained. The most common reality maintenance procedure occurs through conversation. In this case, daily conversations are presented by Kompas.com through narratives about gamers.

Conversations about gamers appeared in kompas.com framing, in the first article the essence of the presence of "contemporary" study programs was due to the phenomenon of gamers. In the second and third articles framing about gamers appointed in the Gamers narrative is no longer a mere game that consumes time but gamers as e-sport athletes who affirm the gamers phenomenon in a positive context. In the fourth and fifth article Gamers was dubbed as a promising profession. Kompas.com frames framing gamers by strengthening speakers from public policy makers both the DPR and the President. In his narrative, relationships are developed between the significant others with self - both interact dialectically in line with the subjective reality that is confirmed together resulting in the identification of gamers in positive meaning.

This conversation flows with the support of language factors which are the linguistic objectivity factors that transform the flow of experience into a cohesive order. Language becomes a tool for actualizing intersubjective experiences. The phrases compiled by kompas.com that gamers are "present", "e-sport athletes", "raise the name of the country" and "opportunity", have succeeded in transforming the meaning of gamers who were originally interpreted lazy and antisocial into gamers in a positive context.

One of the successes of socialization is determined by the level of social structure, in this case the taking of resource persons from the legislative structure encourages the transformation of the meaning of gamers.

\section{Conclusion}

Based on the results of the research and discussion, the framing gamers in kompas.com show that the objective reality of gamers is manifested through externalizing gamers' activity in a positive stigma, as a promising profession opportunity, as a phenomenon of e-sport athletes to opportunities in universities to open up current study programs. The reality of gamers is a social reality that has objective and subjective dimensions. This objective reality through internalization is absorbed by individuals as a subjective reality. This dialectical process takes place in online media including in this case kompas.com. The dialectical process that continues and consists of three moments: externalization, objectivation and internalization. 


\section{References}

[1]. Bagong, Suyanto. (2010). Metode Penelitian Sosial. Jakarta: Prenada Media Group. Burhan Bungin.(2015). Konstruksi Sosial Media Masa. Jakarta. Kencana Prenada Media. Durham And London. (1992).Toward History Of Game Theory. London. Duke University

[2]. Press. Eriyanto. (2009). Analisis Framing, Konstruksi, Ideologi, Dan Politik Media. Yogyakarta:Lkis.

[3]. Ernest Adam. (2014). Fundamentals Of Game Design 3rd Edition. Pearson Educatin,Inc. Henry, Khamadi. (2016). Dampak Digital Gagme Terhadapperkembangan Sosial Budaya Masyarakat.Semarang: Andharupa.

[4]. Kusumadewi, Theodora Natalia. (2009). Hubungan Antara Kecanduan Internet Game Online Dengan Keterampilan Sosial Remaja. Jakarta : Fakultas Psikologi Universitas Indonesia.

[5]. Peter L. Berger, Thomas Luckmann (1967).The Social Construction Of Reality, A Treatise Inthe Sociological Of Knowledge.London : Penguin Books.

[6]. Taylor, SJ Dan R. Bogdan. (1984). Introduction To Qualitative Research Methods: The Search Meanings, Second Edition. Toronto : John Wiley And Sons. 